\title{
Diversity and distribution of crustaceans from 13 sheltered sandy beaches along São Sebastião Channel, south-eastern Brazil
}

\author{
P.R. Nucci*, A. Turra ${ }^{\dagger}$ and E.H. Morgado ${ }^{\dagger}$ \\ *PG-Zoologia Unesp-Rio Claro; ${ }^{\dagger}$ Departamento de Zoologia, IB, UNICAMP, CP 6109, \\ 13083-970 Campinas, SP, Brazil. E-mail: paulonucci@hotmail.com
}

\begin{abstract}
The crustacean species composition in the intertidal zones of 13 sheltered unconsolidated marine beaches in south-eastern Brazil is described. Fifty-three crustacean species were collected, adding 46 species to the total reported by previous studies in the same region. Decapods dominated the community, in contrast to exposed sandy beaches where peracarids normally predominate. The species were distributed irregularly among the beaches. Richness varied markedly among sites, and was positively related to a combination of factors such as fine sand grains, high organic matter content, and relatively low siltclay content. The presence of rock fragments enabled both rocky shore and sandy beach crustaceans to occur on the same beaches. Richness and abundance of crustaceans showed no clear relationship to sediment grain size and slope, in contrast to the norm for exposed sandy beaches. The dominance of the tanaid Kalliapseudes schubarti in some areas may be a result of organic matter pollution in the region. These beaches showed higher species richness than typical sheltered and exposed sandy beaches, indicating that this sheltered, highly heterogeneous seascape is an important area for conservation.
\end{abstract}

\section{INTRODUCTION}

Sandy beaches are dynamic environments with unstable sediments caused by tides and wave action. The organisms in such beaches are behaviourally and physiologically adapted to these physical conditions, mainly in the intertidal zone where periodic exposure to the air also influences the presence and survival of organisms (Brown \& McLachlan, 1990).

In general, the different macrofaunal groups show particular responses to environmental factors, related mainly to substrate composition (Gray, 1974; Whitlatch, 1981; Snelgrove \& Butman, 1994; Hall, 1994; McLachlan, 1996). Substrate heterogeneity may also directly influence species richness and diversity (Gray, 1974; Abele, 1976; Hendrickx, 1996). Organic enrichment may also influence such communities, causing dominance of a few opportunistic species and reduction in species diversity (Pearson \& Rosenberg, 1978; Warwick, 1986).

Polychaetes, molluscs and crustaceans are the dominant invertebrate groups in sandy beaches worldwide (Dexter, 1983, 1984; McLachlan, 1983; Amaral et al., 1990). Polychaetes are most abundant and have more species in areas with low hydrodynamism and fine sand (Dexter, 1983, 1984), sand mixed with rock fragments (Rizzo \& Amaral, 2000) and high organic matter content (Amaral et al., 1990). Molluscs are second in abundance to polychaetes, while crustaceans are least and also have the fewest species. Although crustaceans may be proportionally more abundant in sandy beaches subjected to strong, frequent wave action (Dexter, 1983, 1984; McLachlan et al., 1993), their species richness is still generally low (up to 16 species) (McLachlan et al., 1981; Dexter, 1984; McLachlan, 1990; Defeo et al., 1992;
Jaramillo et al., 1993; McLachlan, 1996). Studies in sheltered environments are rare and generally conducted in estuaries, where salinity varies widely and where input of sediment and nutrients is constant.

We evaluated the species composition of the crustacean communities of the intertidal zones of sheltered, nonestuarine sandy beaches. Spatial distribution among areas was investigated, testing for habitat-specific relationships by contrasting environmental variables and species composition.

\section{MATERIALS AND METHODS}

São Sebastião Channel is located on the northern coast of the state of São Paulo, Brazil, between São Sebastião Island and the mainland. The channel is bounded by Canas Top $\left(45^{\circ} 21^{\prime} \mathrm{W} 23^{\circ} 43^{\prime} \mathrm{S}\right)$ to the north and Sela Top $\left(45^{\circ} 27^{\prime} 30^{\prime \prime} \mathrm{W} 23^{\circ} 52^{\prime} 30^{\prime \prime} \mathrm{S}\right)$ to the south. Along the channel are sandy beaches, with different substrate compositions varying from mud to coarse sand with rock fragments and shell debris. We selected 13 intertidal environments along the channel for study (Figure 1). Enseada, Cigarras, São Francisco, Pontal da Cruz, Araçá (I and II), Grande, Segredo, and Barequeçaba beaches are located on the mainland, while Garapocaia, Siriúba, Engenho d'Água, and Barra Velha beaches are located on São Sebastião Island. Two areas on Araçá Beach were selected in order to include the full range of habitats in this area. These are low-energy sandy beaches according to the exposure rating system of McLachlan (1980), with a maximum tidal range of $2 \mathrm{~m}$ (Furtado \& Mahiques, 1990).

A $10-\mathrm{m}$ wide strip was marked at each site, including the entire intertidal zone from mean high waterline, 


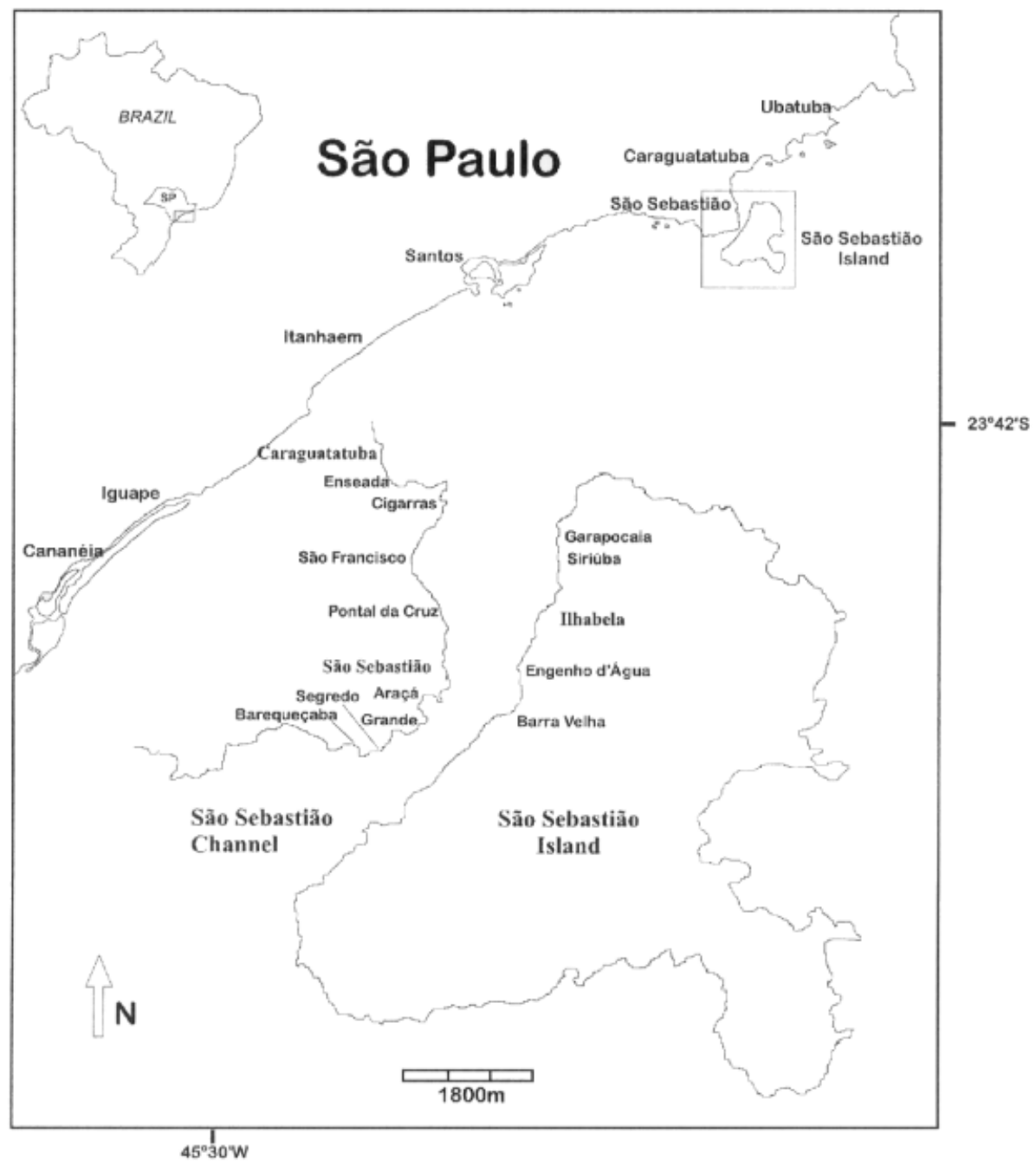

Figure 1. The 13 beaches studied along the São Sebastião Channel on the northern coast of the state of São Paulo, south-east Brazil.

MHW, to mean low waterline, MLW. The strips were divided into three strata $(10 \times 10 \mathrm{~m})$ representing the upper, middle and lower intertidal zones. Random samples were taken monthly from each stratum and site with a small (five samples, $0.01 \mathrm{~m}^{2}$ ) and a large (three samples, $0.16 \mathrm{~m}^{2}$ ) corer from August 1995 to July 1996. The position of each sample was determined by sorting two co-ordinates (one parallel and another perpendicular to the waterline) within each $10 \times 10 \mathrm{~m}$ stratum. The small corer was used to collect polychaetes for another study, and the crustaceans sampled were included in our analysis. The sediment was collected to a depth of $20 \mathrm{~cm}$, and in the laboratory was washed through two superimposed sieves of 0.5 and $1.0 \mathrm{~mm}$ mesh. (This sampling procedure may be not adequate for organisms such as Emerita brasiliensis, Callichirus major and Callichirus mirim, which burrow deeper into the sediment.) The macrofauna was preserved in $70 \%$ alcohol and identified to species. Salinity of the interstitial water was recorded monthly. Sediment grain size (Suguio, 1973) and calcium carbonate and organic matter content (Amoreux, 1966) were recorded seasonally for each site. The slope of the study sites was also measured once during the study.

The density of individuals recorded in each sample of two corer sizes was converted to ind. $\mathrm{m}^{-2}$. The mean density of individuals of each species in each area was calculated by taking the monthly means of all samples; annual or total densities were calculated based on these monthly means. The total densities provided an overall estimate of richness and diversity (Shannon, $\log _{2}$ ) for each beach over the entire study period. An analysis of variance (ANOVA) followed by a post-hoc Scheffés test was performed to compare the density of crustaceans with environmental variables among the sampling areas, using temporal controls as predicting units. A cluster analysis was done to group the sites according to environmental variables and species density (square-root-transformed) using Ward's method and Euclidean distance. Canonical correspondence analysis (CCA) was performed (Hill, 1979) with standardized data, with each variable given equal weight, to verify the relationships of species composition and abundance to the environmental variables. Environmental variables were also related to crustacean richness through a stepwise backward general linear model.

\section{RESULTS}

Environmental variables

Physical and chemical variables varied markedly among sampling areas, reflecting the high environmental 


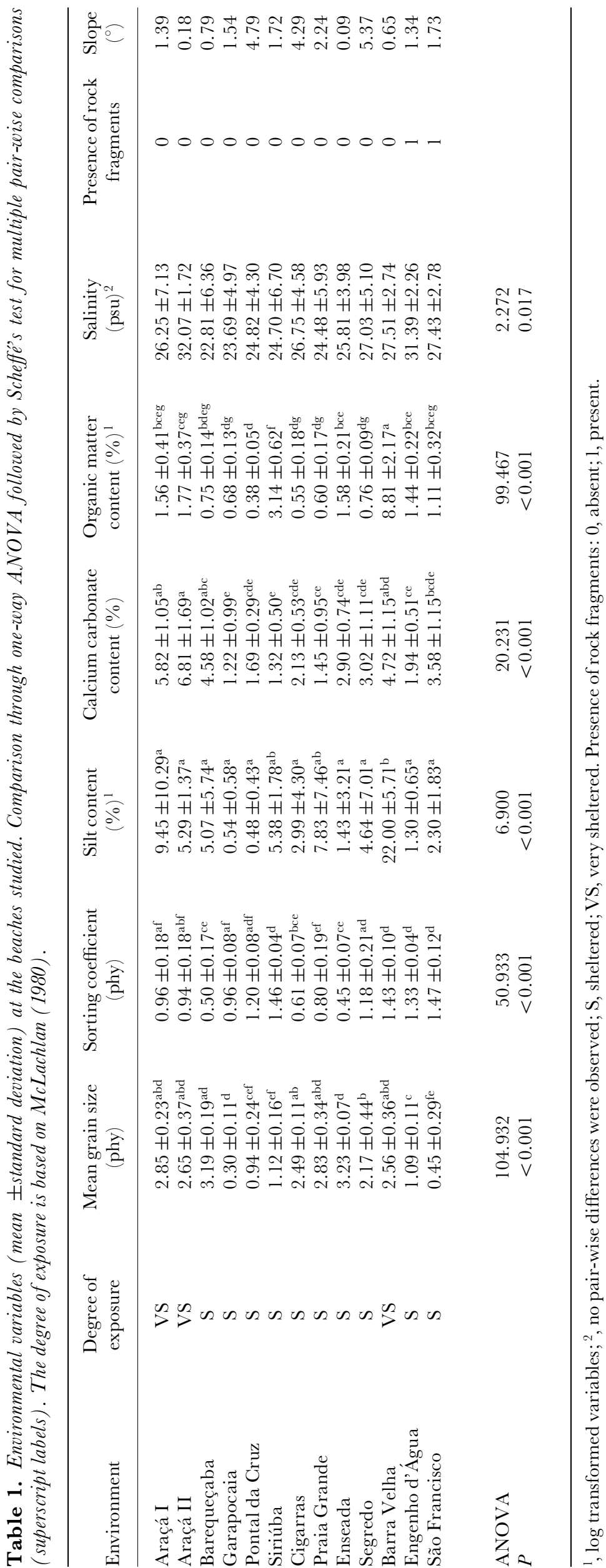


diversity of the sandy beaches along São Sebastião Channel (see Table 1 for ANOVA results). In general, poorly sorted fine sand grains with low silt, calcium carbonate, and organic matter contents dominated in these areas (Table 1). The beaches generally had gentle slopes $\left(0.09^{\circ}\right.$ on Enseada to $5.37^{\circ}$ on Segredo) and small variations in salinity (Table 1). São Francisco and Engenho d'Água beaches consisted of sand mixed with rock fragments and, together with Garapocaia and Siriúba, had coarse sand, in contrast to their relatively low slopes. Variation in intertidal slope was related to the mean sediment grain size (phi units) when only the other beaches were considered ( $\mathrm{N}=9 ; r=-0.722 ; P=0.028)$.

Cluster analysis revealed that Araçá I, Araçá II, Barequeçaba, and Enseada had strong similarities, i.e. smaller sand grains and low slope compared to the other beaches (Table 1, Figure 2A). The high similarity among Araçá I, Araçá II and Barequeçaba was due to their high silt-clay and calcium carbonate contents (Table 1). Enseada was less similar to the other beaches because of its relatively low slope $\left(0.09^{\circ}\right)$, highly sorted fine and very fine sand, and low contents of silt-clay and calcium carbonate. A second group was formed by Cigarras,
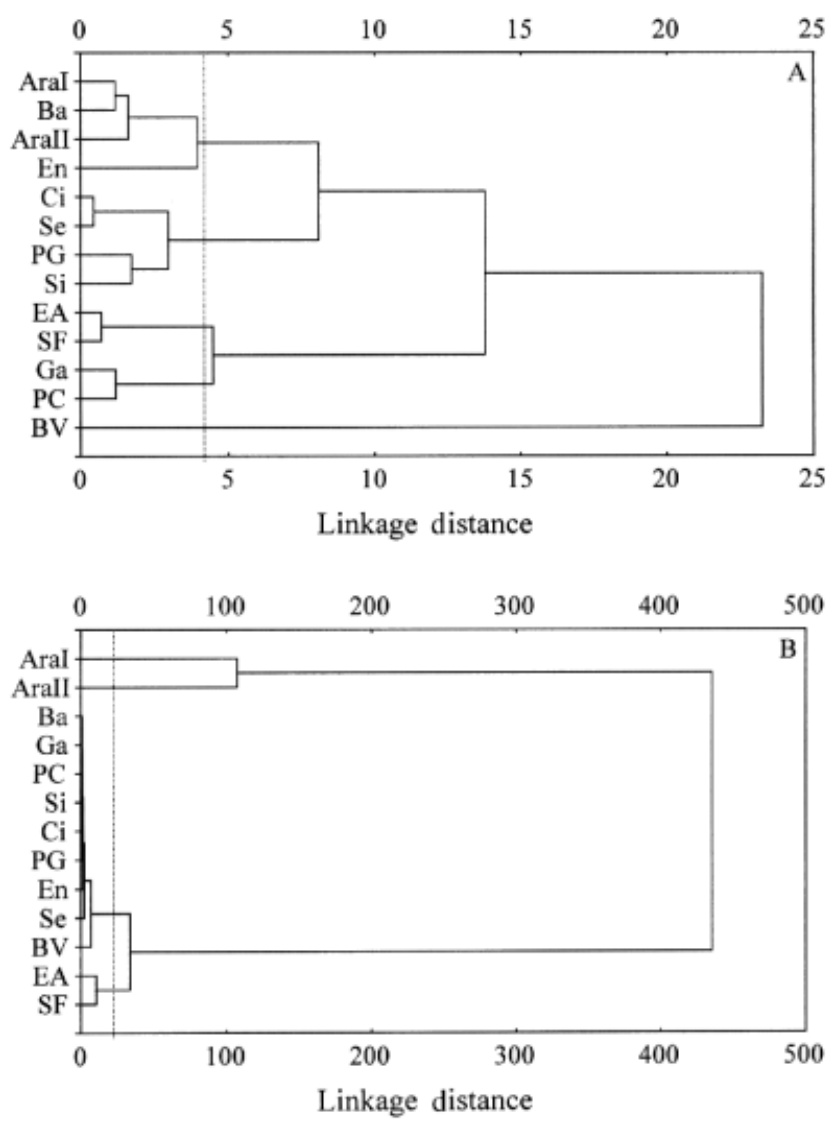

Figure 2. Clustering of 13 beaches along the São Sebastião Channel, based on environmental variables (A) and crustacean densities (B). The data were square-root-transformed, giving equal weight to all species and variables, and using Ward's method and Euclidean distance. Vertical dotted lines, cut-off values for each cluster. Ara I, Araçá site I; Ara II, Araçá site II; Ba, Barequeçaba; BV, Barra Velha; Ci, Cigarras; EA, Engenho d'Água; En, Enseada; Ga, Garapocaia; PC, Pontal da Cruz; PG, Praia Grande; Se, Segredo; SF, São Francisco; Si, Siriúba.
Segredo, Praia Grande and Siriúba, and was characterized by relatively higher slopes and poorly sorted fine to medium sand with low organic matter content (except Siriúba) (Table 1). Engenho d'Água and São Francisco were grouped due to the presence of rock fragments, poorly sorted medium to coarse sand, and intermediate organic matter content. Although Garapocaia and Pontal da Cruz differed little in sediment grain size, they both had relatively high slopes and low silt-clay, calcium carbonate and organic matter contents (Table 1). Barra Velha was much different from the other beaches, with extremely high silt-clay and organic matter contents associated with poorly sorted fine sand (Table 1).

\section{Species composition}

A total of 2659 individuals were collected, belonging to 53 species (Table 2) and 25 families. Members of the Decapoda were most common, with 24 species and eight families, and the Xanthidae and Upogebiidae were numerically important. The tanaid Kalliapseudes schubarti outnumbered the other species in abundance (1672 ind.) and density $\left(20.23 \pm 91.89\right.$ ind. $\left.\mathrm{m}^{-2}\right)$ on some beaches. Hexapanopeus schmitti, Upogebia vasquezi, Upogebia omissa and Alpheus sp. were also frequent, but like the other species were irregularly distributed among sites (Table 3). Crustacean density varied markedly among sites (ANOVA, $F=32.115 ; \mathrm{df}=12 ; P<0.001$ ), being highest at Araçá I and II, Engenho d’Água and São Francisco.

\section{Spatial distribution}

Cluster analysis of the beaches according to species density showed three groups (Figure 2B). One group, Araçá I and II, had extremely high abundance of Kalliapseudes schubarti. This species occurred in lower densities in Enseada and Barra Velha beaches. The latter sites were clustered with Barequeçaba, Garapocaia, Pontal da Cruz, Siriúba, Cigarras, Grande and Segredo beaches in a second group, with low richness and diversity. The third group was formed by Engenho d'Água and São Francisco beaches, which had the highest diversity and richness of crustaceans, mainly decapods.

\section{Species vs. environmental variables}

Mean grain size, sorting coefficient, intertidal slope and calcium carbonate content significantly influenced the ordination (CAA) of sites and species (Figure 3). Araçá I, Araçá II and Barequeçaba were grouped by their fine to very fine sands and high calcium carbonate content, as well as the great abundance of Kalliapseudes schubarti at the first two sites. Steep slopes were associated with low abundance and richness (Grande, Pontal da Cruz, Segredo and Cigarras beaches). The relatively steep slope and coarse grain size at Garapocaia Beach were also correlated with the relatively low abundance and richness of crustaceans at that site. Siriúba Beach showed higher richness, diversity and abundance, despite its steeper slope and coarser grains. There was high richness and diversity at São Francisco and Engenho d'Água beaches. Barra Velha Beach was grouped with São Francisco and 
Table 2. Crustacean species collected in the intertidal zones of sandy beaches along the São Sebastião Channel in three different studies.

Present study

Clibanarius vittatus (Bosc, 1802)

Clibanarius antillensis Stimpson, 1859

Pagurus criniticornis (Dana, 1852)

Pagurus brevidactylus (Stimpson, 1858)

Petrolisthes galathinus (Bosc, 1801-1802)

Petrolisthes armatus (Gibbes, 1850)

Callinectes ornatus Ordway, 1863

Callinectes danae Smith, 1869

Charybdis helleri (A. Milne Edwards, 1867)

Parapinnixa bouvieri Rathbun, 1918

Pinnixa chaetopterana Stimpson, 1860

Pinnixa patagoniensis Rathbun, 1918

Pinnixa sayana Stimpson, 1860

Alarconia guinotae Coelho, 1996

Microphrys bicornutus (Latreille, 1825)

Panopeus americanus Saussure, 1857

Panopeus rugosus A. Milne Edwards, 1880

Panopeus austrobesus Williams, 1983

Panopeus occidentalis Saussure, 1857

Hexapanopeus paulensis Rathbun, 1930

Hexapanopeus schmitti Rathbun, 1930

Eurypanopeus abbreviatus (Stimpson, 1860)

Micropanope urinator (A. Milne Edwards, 1881)

Pilumnus dasypodus Kingsley, 1879

Menippe nodifrons Stimpson, 1859

Cyrtoplax spinidentata (Benedict, 1892)

Eucratopsis crassimanus (Dana, 1852)

Uca thayeri Rathbun, 1900

Pachygrapsus transversus (Gibbes, 1850)

Kalliapseudes schubarti Mañe-Garzon, 1949

Upogebia vasquezi Ngoc-Ho, 1989

Upogebia noronhensis Fausto-Filho, 1969

Upogebia brasiliensis Holthuis, 1956

Upogebia careospina Williams, 1993

Upogebia inomissa Williams, 1993

Upogebia omissa Gomes Corrêa, 1968

Upogebia marina Coêlho, 1973

Acanthosquilla digueti Coutière, 1905

Cymadusa filosa Savigny, 1816

Elasmopus pectenicrus (Bate, 1862)

Parhyale hawaiensis (Dana, 1853)

Grandidierella bonnieroides Stephensen, 1947

Parhyalellasp.

Orchestia sp.

Lepidopa venusta Stimpson, 1860

Lepidopa richmondi Benedict, 1903

Emerita brasiliensis Schmitt, 1935
Litopenaeus schmitti (Burkenroad, 1936)

Xiphopenaeus kroyeri (Heller, 1862)

Hippolytidae

Ogyrididae

Alpheus sp.

Isopoda

Amaral et al. (1990)

Stomatopoda

Lembos foresti, Matheus \& Matheus, 1966

Leucothoe denticulate (syn. L. campi Matheus \& Matheus, 1986)

Melita orgasmos K.H. Barnard, 1940

Orchestia sp.

Tiburonella viscana (J. L. Barnard, 1983)

Kalliapseudes schubarti

Excirolana sp.

Ogyrides alpheorostris

Caridea

Upogebia affinis $^{\mathrm{t \dagger}}$

Pagurus criniticornis

Pagurus sp.

Albunea paretii Guérin-Menéville, 1853

Lepidopa websteri ${ }^{\dagger}$

Emerita talpoida ${ }^{\dagger *}$

Majidae

Callinectes danae

Hexapanopeus paulensis

Dissodactylus crinitichelis Moreira, 1901

Pinnixa sayana

Callichirus sp.

Morgado et al. (1990)

Lembos foresti

Leucothoe denticulata

Melita orgasmos

Excirolanasp.

Upogebia affinis $^{\text {t† }}$

Pagurus criniticornis

Pagurus sp.

Albunea paretii

Emerita talpoida ${ }^{\dagger *}$

Majidae

Callinectes danae

Hexapanopeus paulensis

Dissodactylus crinitichelis

Pinnixa sayana

Callichirus sp.

${ }^{\dagger},{ }^{\dagger \dagger}$, species wrongly identified; ${ }^{\dagger}$, corresponds to Lepidopa richmondi Benedict, 1903 and Emerita brasiliensis $\mathrm{Schmitt,} 1935 ;{ }^{\dagger \dagger}$, material not re-examined; *, species common to the present study.

Engenho d’Água by their relatively greater similarity in species composition. The crustacean fauna of Enseada Beach was not dominated by any species, nor was there any significant correlation with environmental variables.

Stepwise backward general linear model revealed a significant relationship between species richness and the presence of rock fragments, mean grain size, and organic matter and silt - clay contents $\left(\mathrm{N}=13, r^{2}=0.978, P<0.001\right.$; Table 4). Richness was positively influenced by organic matter content (log-transformed) and by the presence of rock fragments, and was negatively influenced by mean grain size (in $\mathrm{mm}$ ) and silt-clay content. Abundance of crustaceans was positively correlated with the presence of rock fragments and the calcium carbonate content $\left(\mathrm{N}=13, r^{2}=0.631, P<0.001\right)$ (Table 4$)$. 


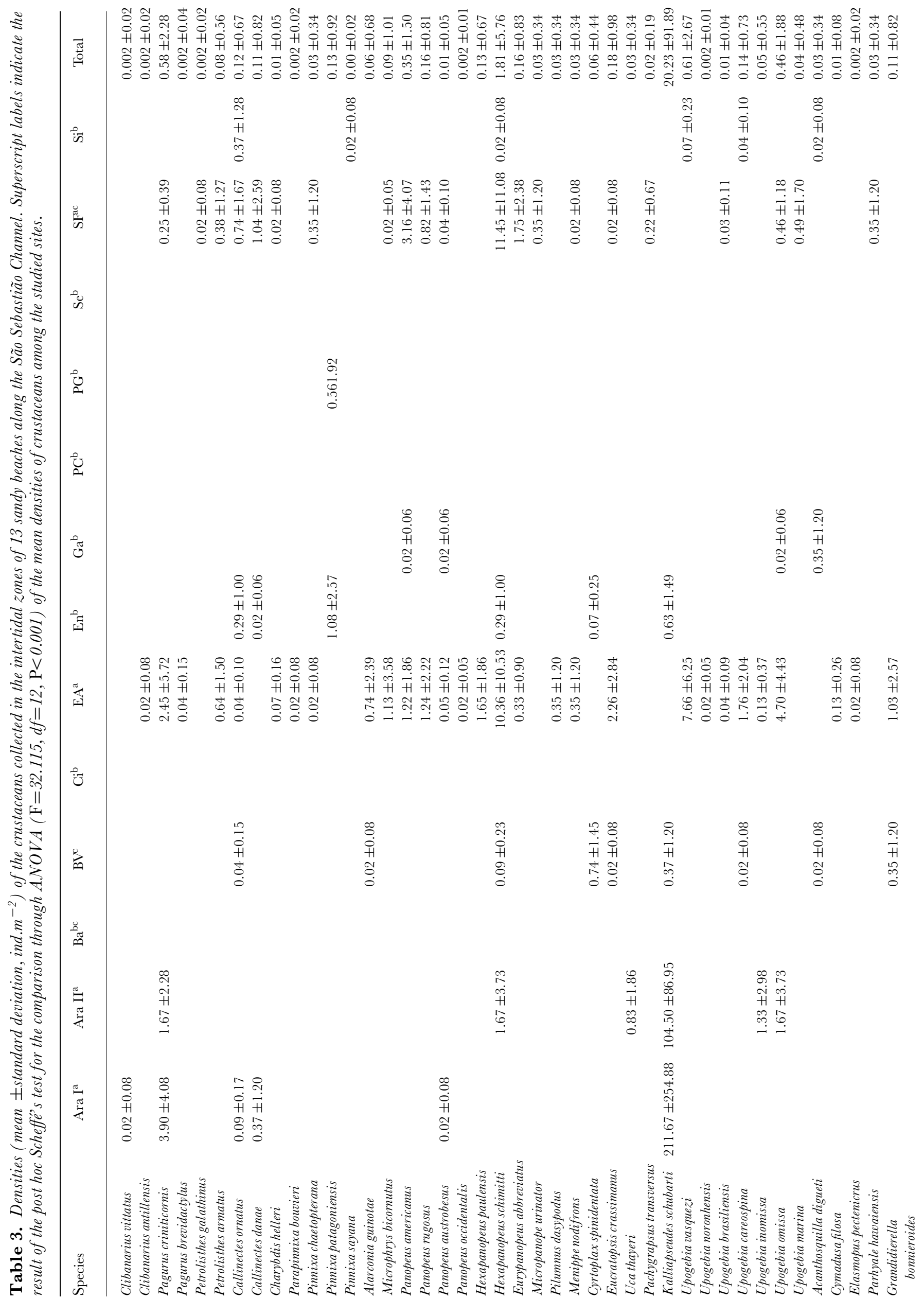




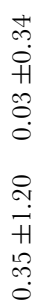

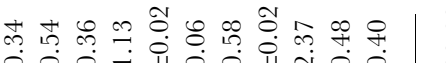

H讠H

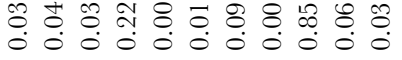

푼
15

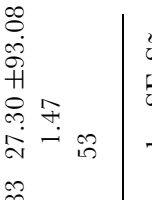

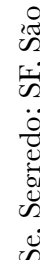

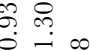

in

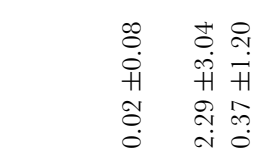

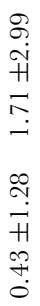

$\infty$
$\stackrel{0}{0}$
$\stackrel{+}{+}$
$\stackrel{0}{0}$

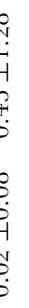

i

-

$\stackrel{n}{\infty}$

H

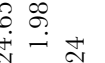

S.

눈

$-$

건

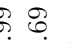

$\dot{\circ} \dot{\circ}$

$\stackrel{0}{\circ}$

(n)

(1)

in

ㄴ.

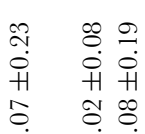

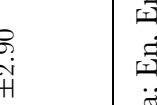

菅

$8-\sigma$

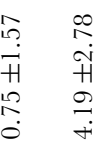

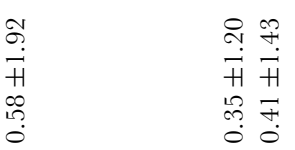

+

F্

离

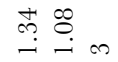

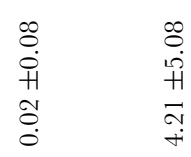

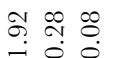

$\dot{H}$ 茾弄

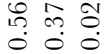

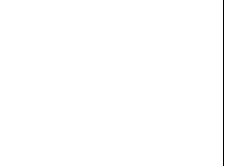

잉

용

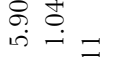

กิ

Hิ

量:

$=$

我

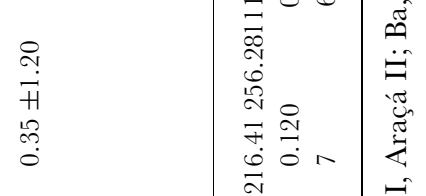

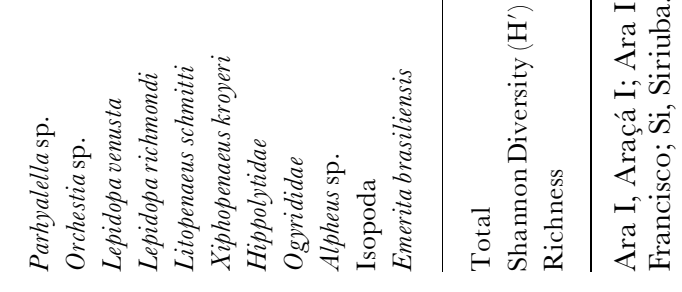




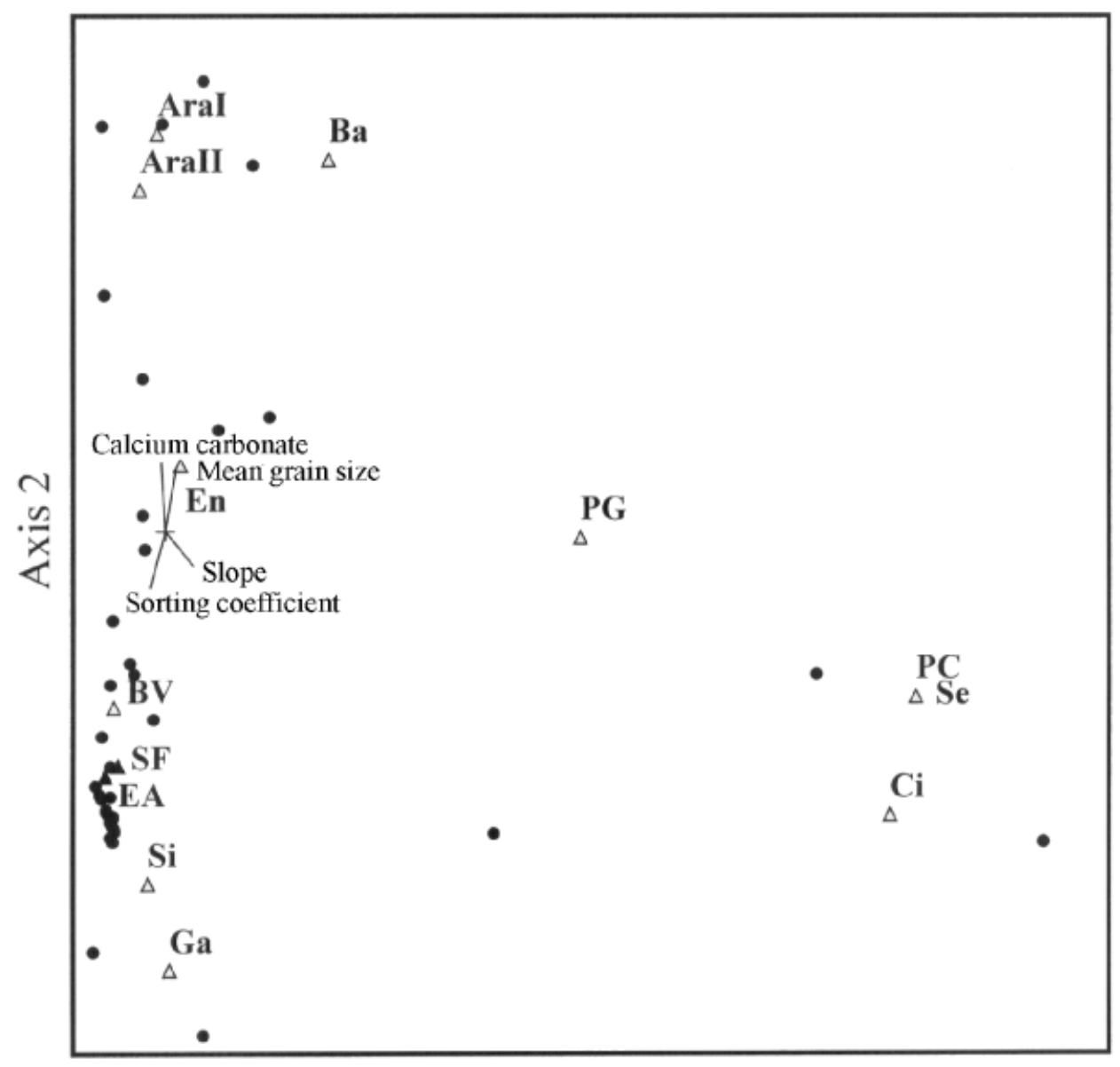

Axis 1

Figure 3. Ordination (canonical correspondence analysis) of 13 beaches along the São Sebastião Channel, based on species densities and environmental variables. Data were square-root-transformed, and equal weight given to all species. Dots, species; triangles, study sites; filled triangles, presence of rock fragments. Per cent of variation explained: axis $1,15.5 \%$; axis $2,15.1 \%$. (Legend: Ara I, Araçá I; Ara II, Araçá II; Ba, Barequeçaba; BV, Barra Velha; Ci, Cigarras; EA, Engenho d’Água; En, Enseada; Ga, Garapocaia; PC, Pontal da Cruz; PG, Praia Grande; Se, Segredo, SF, São Francisco; Si, Siriúba.)

Table 4. Results of the stepwise general linear model analysis indicating those environmental variables which were significantly correlated with crustacean richness and density (log transformed) in the intertidal zones of 13 beaches along the São Sebastião Channel.

\begin{tabular}{lrrr}
\hline Effect & $F$ & df & \multicolumn{1}{c}{$P$} \\
\hline Richness & & & \\
$\quad$ Mean grain size (phi) & 5.591 & 1 & 0.046 \\
$\quad$ Presence of rock fragments & 241.434 & 1 & $<0.001$ \\
$\quad$ Silt-clay content* $\%$ ) & 7.451 & 1 & 0.026 \\
$\quad$ Organic matter content* $\%$ ) & 35.290 & 1 & $<0.001$ \\
Density & & & \\
$\quad$ Calcium carbonate content $(\%)$ & 10.205 & 1 & 0.010 \\
$\quad$ Presence of rock fragments & 8.566 & 1 & 0.015 \\
\hline
\end{tabular}

*, log transformed variables.

\section{DISCUSSION}

The sheltered characteristics of these beaches and the structural differences among them may be associated with the high richness of the intertidal crustacean fauna, compared to the faunas of exposed sandy beaches
(McLachlan et al., 1981; Dexter, 1984; McLachlan, 1990; Defeo et al., 1992; Jaramillo et al., 1993; McLachlan, 1996). Decapods dominated the crustacean assemblage in these environments, in contrast to the dominance of peracarids on exposed sandy beaches. This shift in species dominance was strongly associated with the presence of rocky fragments in some areas, which enabled both sandy beach and rocky shore crustaceans to occur.

The 13 beaches were extremely heterogeneous in respect to physical and chemical variables. In general, there is a direct relationship between the rates of deposition of organic matter and fine sand grains on sandy beaches (Gray, 1974). The high organic matter content in the coarse sediment of Siriúba Beach is an exception, and can be explained by the input of coarse sand and organic matter from an adjacent rivulet. Organic matter content influences the occurrence and distribution of benthic organisms (Rizzo \& Amaral, 2000), and may be responsible for the relatively high richness at Siriúba.

In general, higher species richness was associated with a combination of factors such as finer sand, higher organic matter content, the presence of rock fragments and relatively lower silt-clay content. Our results do not agree with the model proposed by McLachlan (1983) of 
an inverse relationship between sand particle size and slope; and the richness and abundance of the beach fauna. Siriúba, Garapocaia, Pontal da Cruz, Engenho d'Água and São Francisco beaches were characterized by coarse sediments, although they are subjected to gentle wave action, and their crustacean faunas varied in richness and abundance. Areas with fine sand also had variable numbers of species and individuals. In this kind of low-energy environment, particle size may not have the same influence on crustaceans as it does in exposed sandy beaches. Beach slope had no detectable influence on richness, compared to other factors that varied more among beaches. The abundance of crustaceans was influenced both by the presence of rock fragments and the calcium carbonate content, due to the high densities in São Francisco and Engenho d’Água and in Araçá I and II, respectively.

Environmental heterogeneity played an important role in species richness, given that the richest fauna was found in sand sediments mixed with rock fragments (pebbles and cobbles) of São Francisco and Engenho d'Água beaches. Other studies have demonstrated a positive influence of this particular habitat on the composition of polychaete (Rizzo \& Amaral, 2000) and mollusc (Denadai \& Amaral, 1999) assemblages. The influence of habitat heterogeneity on crustacean communities was previously shown by Abele (1976) and Hendrickx (1996). McQuaid \& Dower (1990) studied rocky shores periodically inundated by sand, and demonstrated the positive influence of disturbance and habitat heterogeneity on species richness and diversity.

The present study added 46 species to the total found by previous biological surveys along the São Sebastião Channel. Morgado et al. (1990) and Amaral et al. (1990) recorded 15 and 22 species respectively, or $29 \%$ and $42 \%$ of the total number of species collected in the present study. These two studies employed different sampling methodologies and efforts, and did not include areas composed of sand with rock fragments. On the other hand, they recorded ten species that were not sampled in the present study. Common sandy beach species as Ocypode quadrata and Callichirus major were not found in the present study, because of the high mobility of the former and the depth of the galleries of the latter. The crustacean fauna of the intertidal zones of the sandy beaches along the São Sebastião Channel was composed of at least 64 species.

Some species (Micropanope urinator, Parapinnixa bouvieri, Upogebia vasquezi, Upogebia noronhensis, Upogebia careospina and Upogebia marina) known from northern and northeastern Brazil, were recorded for the first time on the coast of the state of São Paulo (Nucci \& Melo, 1999). The North American Upogebia inomissa was found for the first time in Brazilian waters (Nucci \& Melo, in press). We also recorded the Indo-Pacific brachyuran Charybdis helleri, which was first reported from the Brazilian coast by Carqueija \& Gouvêa (1996) and from the coast of São Paulo State by Negreiros-Fransozo (1996). According to Lemaitre (1995), Charybdis helleri has only recently invaded the Western Atlantic, probably at the end of the 1980s in ballast water of oil tankers. This may explain the occurrence of this species on the coast of São Paulo, since there is an active petroleum port in the São Sebastião
Channel. The consequences for the native fauna of the introduction of this aggressive species are unknown.

The tanaid Kalliapseudes schubarti was the most abundant species in the São Sebastião Channel, but occurred at only four of the 13 sites (Araçá I, Araçá II, Enseada and Barra Velha). This species is associated with fine to very fine sand grains and with higher organic matter content (Amaral et al., 1990; Nucci et al., 1997; F.P.P. Leite et al., unpublished data) and was especially abundant in Araçá I and II, with $>210$ and 104 ind. $\mathrm{m}^{-2}$ respectively. The dominance of this species, associated with the strong human influence causing organic enrichment and sediment alteration at these sites (Amaral \& Morgado, 1994), indicates that it is an opportunist, as previously suggested by Amaral et al. (1990).

We thank the Conselho Nacional de Desenvolvimento Científico e Tecnológico ( $\mathrm{CNPq}$ ) and the Fundo de Apoio à Pesquisa (IB-FAEP/UNICAMP) for their grants in support of this study, and the Centro de Biologia Marinha (CEBIMar/ USP) for logistical support. We acknowledge Dr A. Cecília Z. Amaral for coordinating the project 'Fauna de Praia'. Our gratitude is extended to Dr Gustavo A.S. Melo who identified the crustaceans. Antonio M. Rosa and Élcio S. Marinho (IBUNICAMP) for assistance with fieldwork. Luiz F.L. Duarte, Alexandra E. Rizzo, Márcia R. Denadai and Fosca P.P. Leite commented usefully on the manuscript, and Dr Janet W. Reid revised the English text. We thank the anonymous referee for helpful comments and improvements to the manuscript.

\section{REFERENCES}

Abele, L.G., 1976. Comparative species composition and relative abundance of decapod crustaceans in marine habitats of Panamá. Marine Biology, 38, 263-278.

Amaral, A.C.Z. \& Morgado, E.H., 1994. Alteraciones en la fauna de anelídeos poliquetos de Araça, São Sebastião (SP, Brasil). Revista de la Academia Colombiana de Ciencias Exactas, Físicas y Naturales, 19, 147-152.

Amaral, A.C.Z., Morgado, E.H., Lopes, P.P., Belúcio, L.F., Leite, F.P.P. \& Ferreira, G.P., 1990. Composition and distribution of the intertidal macrofauna of sandy beaches on São Paulo coast. In Simpósio de Ecossistemas da Costa Sul e Sudeste Brasileira: estrutura, função e manejo, 2 v. 2, Águas de Lindóia. Anais (ed. S. Watanabe), pp.258-279. São Paulo: ACIESP Press.

Amoureux, L., 1966. Étude bionomique et écologique de quelques annélides polyquetes des sables intertidaux de côtes ouest de la France. Archives de Zoologie Expérimentale Générale, 107, 1-218.

Brown, A.C. \& McLachlan A., 1990. Ecology of sandy shores. Amsterdam: Elsevier Press.

Carqueija, C.R.G. \& Gouvêa, E.P., 1996. A ocorrência, na costa Brasileira, de um Portunidae (Crustacea, Decapoda), originário do Indo-Pacífico e Mediterrâneo. Nauplius, 4, 105-112.

Defeo, O., Jaramillo, E. \& Lyonnet, A., 1992. Community structure and intertidal zonation of the macroinfauna on the Atlantic coast of Uruguay. Fournal of Coastal Research, 8, 830-839.

Denadai, M.R. \& Amaral, A.C.Z., 1999. A comparative study of intertidal molluscan communities in sandy beaches, São Sebastião Channel, São Paulo State, Brazil. Bulletin of Marine Science, 65, 91-103. 
Dexter, D.M., 1983. Community structure of intertidal sandy beaches in New South Wales, Australia. In Sandy beaches as ecosystems (ed. A. McLachlan and T. Erasmus), pp. 391-403. South Africa: Junk Publishing.

Dexter, D.M., 1984. Temporal and spatial variability in the community structure of the fauna of four sandy beaches in south-eastern New South Wales. Australian Fournal of Marine and Freshwater Research, 35, 663-672.

Furtado, V.V. \& Mahiques, M.M., 1990. Distribuição dos sedimentos em regiões costeiras e plataforma continental norte do Estado de São Paulo. In Simpósio de ecossistemas da costa sul e sudeste brasileira: estrutura, função e manejo, 2 v. 2, Águas de Lindóia, Anais (ed. S. Watanabe), pp. 20-29, São Paulo: ACIESP Press.

Gray, J., 1974. Animal-sediment relationship. Oceanography and Marine Biology. Annual Review, 12, 223-261.

Hall, S.J., 1994. Physical disturbance and marine benthic communities: life in unconsolidated sediments. Oceanography and Marine Biology. Annual Review, 32, 179-239.

Hendrickx, M.E., 1996., Habitats and biodiversity of decapod crustaceans in the SE Gulf of California, México. Revista de Biologia Tropical, 44, 603-617.

Hill, M.O., 1979. Twispan - a Fortran program for arranging multivariate data in a ordered two-way table by classification of the individual and attributes. Ithaca, New York: Cornell University Press.

Jaramillo, E., McLachlan, A. \& Coetzee, P., 1993. Intertidal zonation patterns of macroinfauna over a range of exposed sandy beaches in south-central Chile. Marine Ecology Progress Series, 101, 105-118.

Lemaitre, R., 1995. Charybdis helleri (Milne Edwards, 1867), a nonindigenous portunid crab (Crustacea: Decapoda: Brachyura) discovered in the Indian River lagoon system of Florida. Proceedings of the Biological Society of Washington, 108, 643-648.

McLachlan, A., 1980. The definition of sandy beaches in relation to exposure: a simple rating system. South African Fournal of Science, Cape Town, 76, 137-138.

McLachlan, A., 1983. Sandy beach ecology - a review. In Sandy beaches as ecosystems (ed. A. McLahlan and T. Erasmus), pp. 321-380. South Africa: Junk Publishing

McLachlan, A., 1990. Dissipative beaches and macrofauna communities on exposed intertidal sands. Fournal of Coastal Research, 6, 57-71.

McLachlan, A., 1996. Physical factors in benthic ecology: effects of changing sand particle size on beach fauna. Marine Ecology Progress Series, 131, 205-217.

McLachlan, A., Jaramillo, E., Donn, T.E. \& Wessels, F., 1993. Sandy beach macrofauna communities and their control by the physical environment: a geographical comparison. Fournal of Coastal Research, 15, 27-38. [Special Issue.]
McLachlan, A., Wooldridge, T. \& Dye, A.H., 1981. The ecology of sandy beaches in southern Africa. South African Fournal of Zoology, 16, 219-231.

McQuaid, C.D. \& Dower, K.M., 1990. Enhancement of habitat heterogeneity and species richness on rocky shores inundated by sand. Oecologia, 84, 142-144.

Morgado, E.H., Amaral, A.C.Z., Belúcio, L.F., Lopes, P.P., Ferreira, C.P. \& Leite, F.P.P., 1990. The intertidal macrofauna of São Francisco complex beaches (São Sebastião, SP). In Simpósio de Ecossistemas da Costa Sul e Sudeste Brasileira: estrutura, função e manejo, 2 v. 2, Águas de Lindóia, Anais (ed. S. Watanabe), pp. 314-325. São Paulo: ACIESP Press.

Negreiros-Fransozo, M.L., 1996. The zoea I of Charybdis helleri (A. Milne-Edwards, 1867) (Decapoda, Portunidae) obtained in laboratory. Nauplius, 4, 165-168.

Nucci, P.R. \& Melo, G.A.S., 1999. Novas ocorrências de crustáceos decápodos no litoral do Estado de São Paulo-Brasil. Nauplius, 7, 191-192.

Nucci, P.R. \& Melo, G.A.S., in press. First record of Upogebia inomissa Williams, 1993 (Decapoda, Thalassinidea, Upogebiidae) in Brazil. Nauplius, 8.

Nucci, P.R., Morgado, E.H. \& Amaral, A.C.Z., 1997. Aspectos da distribuição de Kalliapseudes schubarti Mañe-Garzon, 1949 (Crustacea, Tanaidacea) na região do Araçá, São Sebastião (SP-Brasil). In Congresso latino-americano sobre ciências do mar, Santos. Resumos expandidos (ed. A.M. Paiva Filho), pp. 223-224. IOUSP/ALICMAR/FIESP.

Pearson, T.H. \& Rosenberg, R., 1978. Macrobenthic succession in relation to organic enrichment and pollution of the marine environment. Oceanography and Marine Biology. Annual Review, 16, 229-311.

Rizzo, A.E. \& Amaral, A.C.Z., 2000. Temporal variation of annelids in the intertidal zone of beaches of the São Sebastião Channel, southern Brazil. Journal of the Marine Biological Association of the United Kingdom, 80, 1007-1017.

Snelgrove, P.V.C. \& Butman, C.A., 1994. Animal-sediment relationships revisited: cause vs. effects. Oceanography and Marine Biology. Annual Revierw, 32, 111-177.

Suguio, K., 1973. Introdução à sedimentologia. São Paulo: Blucher/ Edusp.

Warwick, R.M., 1986. A new method for detecting pollution effects on marine macrobenthic communities. Marine Biology, 92, 557-562.

Whitlatch, R.B., 1981. Animal-sediment relationships in intertidal marine benthic habitats: some determinants of depositfeeding species diversity. Fournal of Experimental Marine Biology and Ecology, 53, 31-45.

Submitted 2 January 2001. Accepted 11 April 2001. 